\title{
REVIEW ARTICLE Inhibiting cancer cell hallmark features through nuclear export inhibition
}

\author{
Qingxiang Sun ${ }^{1,2}$, Xueqin Chen ${ }^{2}$, Qiao Zhou ${ }^{2}$, Ezra Burstein ${ }^{3,4}$, Shengyong Yang ${ }^{1}$ and Da Jia ${ }^{1,5}$
}

Treating cancer through inhibition of nuclear export is one of the best examples of basic research translation into clinical application. Nuclear export factor chromosomal region maintenance 1 (CRM1; Xpo1 and exportin-1) controls cellular localization and function of numerous proteins that are critical for the development of many cancer hallmarks. The diverse actions of CRM1 are likely to explain the broad ranging anti-cancer potency of CRM1 inhibitors observed in pre-clinical studies and/or clinical trials (phase I-III) on both advanced-stage solid and hematological tumors. In this review, we compare and contrast the mechanisms of action of different CRM1 inhibitors, and discuss the potential benefit of unexplored non-covalent CRM1 inhibitors. This emerging field has uncovered that nuclear export inhibition is well poised as an attractive target towards low-toxicity broad-spectrum potent anti-cancer therapy.

Signal Transduction and Targeted Therapy (2016) 1, 16010; doi:10.1038/sigtrans.2016.10; published online 1 July 2016

\section{INTRODUCTION}

Nuclear export, mainly mediated by the nuclear export factor exportin-1 (better known as chromosomal region maintenance 1, CRM1), is an essential function in all eukaryote that transport nuclear export signal (NES) containing cargoes from the nucleus to the cytoplasm.' Upregulation of this process is a common characteristic for a broad spectrum of cancers; inhibition of nuclear export kills cancer cells effectively, although its anti-cancer mechanism is not conclusive thus far. ${ }^{2,3}$ In addition, CRM1 has been shown to mediate drug resistance. ${ }^{4,5}$ Among dozens of CRM1 inhibitors discovered, a few were clinically tested or are undergoing clinical trials, including the first generation of CRM1 inhibitor, leptomycin B (LMB), and the second-generation CRM1 inhibitor SINE (specific inhibitor of nuclear export). ${ }^{6}$ In this review, we first present the background of nuclear-cytoplasmic transport, the nuclear export factor CRM1 and the cancer hallmark pathways affected by CRM1 inhibition. We then discuss the details of LMB and SINE, with both being covalent CRM1 inhibitors. Finally, we propose non-covalent CRM1 inhibitors as the next generation of anti-cancer drugs, and discuss their advantage over covalent inhibitors.

\section{NUCLEOCYTOPLASMIC TRANSPORT}

Eukaryotes are characterized by the presence of the cell nucleus, which is enclosed by a nuclear envelope and separated from the rest of the cell. The nuclear pore complex (NPC) is the sole gateway on the nuclear envelope that governs protein and nucleic acid exchange between the nucleus and cytosol. ${ }^{7}$ Although small molecules are freely permeable across the NPC, permeability is increasingly restricted as the molecular size approaches $30 \mathrm{kDa}{ }^{8}$ Movement of bigger molecules or more efficient passage of smaller molecules in and out of the nucleus is mediated by active transport of soluble transport factors called karyopherin proteins. ${ }^{9,10}$ The human genome encodes $\sim 20$ different karyopherin proteins, functioning as importin (for nuclear import), exportin (for nuclear export) or transportin (both import and export), each being responsible for transporting a set of cargoes (protein or RNA) containing specific sequences/motifs known as nuclear localization signal (NLS) or NES or both. ${ }^{11-15}$ Karyopherin directly binds to exposed NLS or NES, and determine whether the cargo should go to the cytoplasm or nucleus. Diverse mechanisms, such as post-translational modifications (phosphorylation, acetylation, sumoylation, ubiquitination and so on), protein binding masking/unmasking and disease-related NES mutations, regulate cargo's NES/NLS accessibility and thus its cellular localization. ${ }^{16-21}$

For nuclear import, a cargo with accessible NLS and an importin form a complex, which is imported into the nucleus together through the NPC (Figure 1).22,23 The small GTPase RanGTP in the nucleus then dissociates the cargo from the importin through direct or indirect competition. ${ }^{24,25}$ The RanGTP-importin complex is then recycled to the cytoplasm. After GTP hydrolysis by RanGAP and concomitant RanGDP dissociation, importin is ready for another cycle of nuclear import. ${ }^{26,27}$ For a cargo to exit the nucleus, it must display an NES, which cooperatively forms a tight trimeric complex with an exportin and RanGTP. ${ }^{28-30}$ The complex translocates together into the cytoplasm, where RanGTP is hydrolyzed to RanGDP by RanGAP. This weakens the affinity between NES and exportin, causing dissociation of cargoes. ${ }^{31}$ Bidirectional karyopherins bind to NLS cargoes in the cytoplasm and bind to NES cargoes when exiting nucleus, with similar cargo association/dissociation mechanism to importins and exportins discussed above. ${ }^{32,33}$

\section{NUCLEAR EXPORT FACTOR CRM1}

Of the known exportins, CRM1 is an essential and most often used exportin in cells, which exports numerous cargoes including both proteins and RNAs. ${ }^{1,34-36}$ More than 1050 cargoes have been

\footnotetext{
${ }^{1}$ State Key Laboratory of Biotherapy and Collaborative Innovation Center of Biotherapy, Sichuan University, Chengdu, China; ${ }^{2}$ Department of Pathology, West China Hospital, Sichuan University, Chengdu, China; ${ }^{3}$ Department of Internal Medicine, UT Southwestern Medical Center, Dallas, Texas, USA; ${ }^{4}$ Department of Molecular Biology, UT Southwestern Medical Center, Dallas, Texas, USA and ${ }^{5}$ West China 2nd University Hospital, Sichuan University, Chengdu, China. 


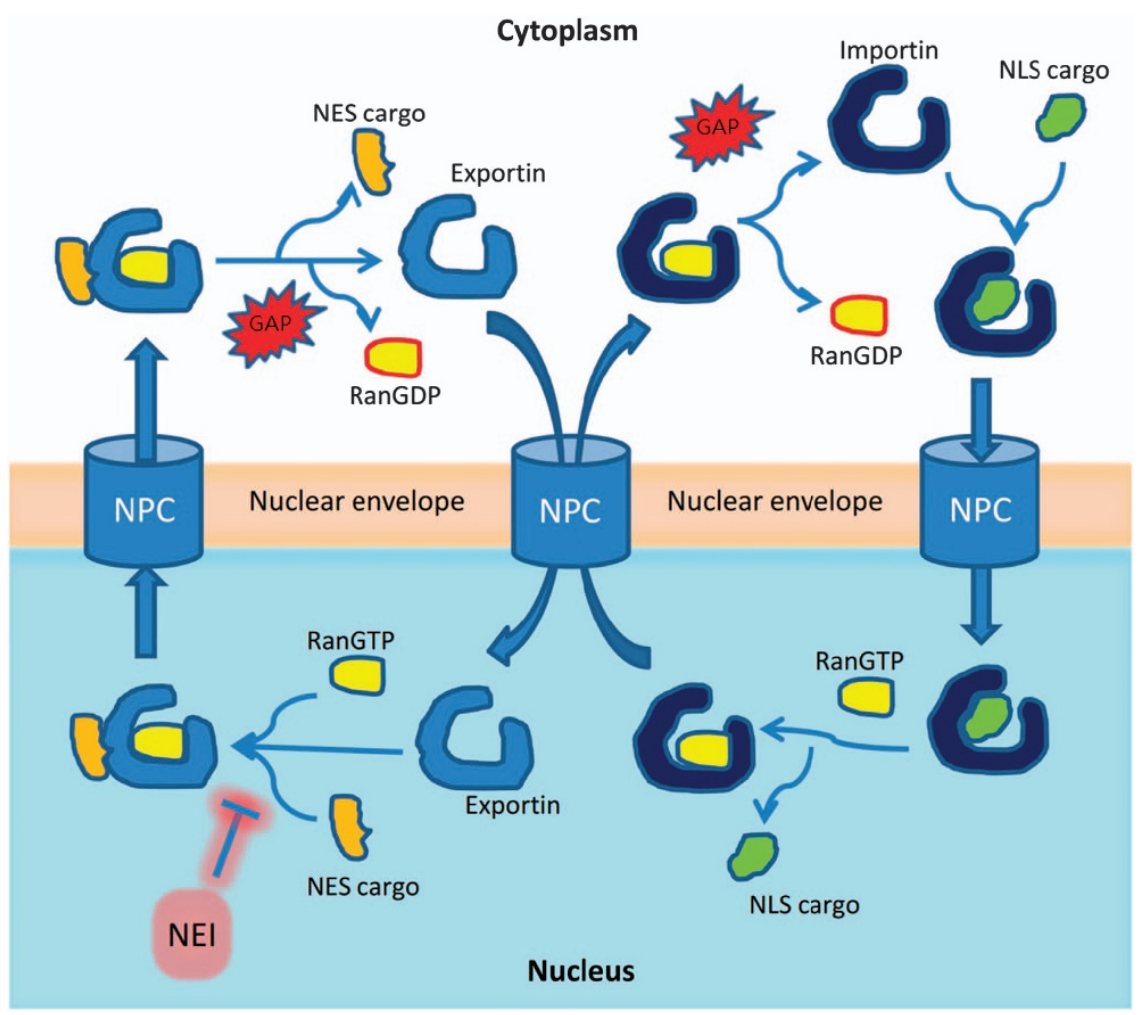

Figure 1. An overview of nucleocytoplasmic transport. Nucleocytoplasmic transport requires cargo with accessible NES or NLS, and its corresponding transport factor exportin or importin. For simplicity, bidirectional keryopherin-mediated transport is omitted. GAP, GTPaseactivating protein; NEl, nuclear export inhibitor; NES, nuclear export signal; NLS, nuclear import signal; NPC, nuclear pore complex; RanGDP and RanGTP, GDP- and GTP-bound form of the small GTPase protein Ran.

identified in human cells through proteomic approaches, among which $>200$ cargoes have been verified through different techniques. ${ }^{37-40}$ CRM1-mediated nuclear export is implicated in various diseases, including cancer, wound healing, inflammation and viral infection. This review will focus on its role in cancer. ${ }^{6,41,42}$ CRM1 is overexpressed in a large variety of tumors including lung cancer ${ }^{43}$ osteosarcoma ${ }^{44}$ glioma, ${ }^{45}$ pancreatic cancer ${ }^{46}$ ovarian cancer, ${ }^{47,48}$ cervical carcinoma, ${ }^{49}$ renal cell carcinoma, ${ }^{50}$ esophageal carcinoma, ${ }^{51}$ gastric carcinoma, ${ }^{52}$ hepatocellular carcinoma, ${ }^{53}$ acute myeloid/lymphoid leukemia, ${ }^{54,55}$ chronic myeloid/lymphoid leukemia, ${ }^{56}$ mantle cell lymphoma, ${ }^{57,58}$ plasma cell leukemia ${ }^{59}$ and multiple myeloma. ${ }^{59,60}$ In addition, CRM1 upregulation is associated with drug resistance and stands out as a poor prognosis factor in many malignancies. ${ }^{44-46,52,54,61-67}$

CRM1 exports a long list of tumor suppressors or oncogenes, such as p53, FOXOs, p27, nucleophosmin, BCR-ABL, elF4E and survivin, and these proteins are mislocalized to the cytoplasm in many cancer cell types (Figure 2). ${ }^{6,68-71}$ Furthermore, acting through a variety of mechanisms, CRM1 activates or upregulates the expression of several oncogenic proteins that may not be the direct cargo of CRM1, such as vascular endothelial growth factor, epidermal growth factor receptor, Cox-2, c-Myc and HIF-1 (Figure 2). ${ }^{63,72,73}$ Thus, inhibition of CRM1-dependent nuclear export may affect multiple aspects of carcinogenesis.

\section{DOWNREGULATING CANCER HALLMARKS THROUGH CRM1 INHIBITION}

During the multistep development of cancer, cells acquire unique biological properties that enable them to become neoplastic and eventually malignant. ${ }^{74}$ These properties include genomic instability, sustained proliferation, resistance to cell death, reprogramming of cellular energetics and so on, which are summarized as the hallmarks of cancer by Hanahan and Weinberg. ${ }^{75}$ Intriguingly, many CRM1 cargoes are found to be critical for at least nine hallmark features of cancer (Figure 2). Next, we will briefly discuss how the altered cellular distribution of CRM1 cargoes contributes to a particular cancer hallmark, and how CRM1 inhibition may reverse these processes, hopefully bringing some insights into CRM1 inhibitors' broad-spectrum anticancer activity.

\section{Sustained proliferation}

The most remarkable trait that cancer cells acquire is their ability to perpetually divide, resulting in uncontrolled proliferation. ${ }^{76}$ Many tumor-specific mechanisms are involved in this particular cancer cell trait. For instance, the proto oncogene $B C R-A B L$ is formed by a fusion of the ABL1 (Abelson murine leukemia viral oncogene homolog 1) and the $B C R$ (breakpoint cluster region) genes, resulting in a $B C R-A B L$ chimeric protein, which constantly stimulates proliferation of myeloid cells. ${ }^{7,78}$ BCR-ABL is exported to the cytoplasm of cancer cells where it activates the PI3K/Akt pathway. ${ }^{77,79}$ CRM1 inhibition traps BCR-ABL in the nucleus, resensitizes leukemia cells to the $B C R-A B L$ inhibitor imatinib, resulting in strong reduction of tumor cell proliferative potential with limited toxicity to normal myeloid precursors. ${ }^{80,81}$ In addition, the expression level of several master growth regulators, such as c-Myc, c-Met and epidermal growth factor receptor, is reduced by CRM1 inhibition through different mechanisms, which might be crucial for the reduced rate of tumor proliferation observed. . $^{5,59,60,82,83}$

\section{Evading growth suppressors}

Tumors evade powerful negative regulation of cell proliferation imposed by different growth suppressors such as retinoblastoma 


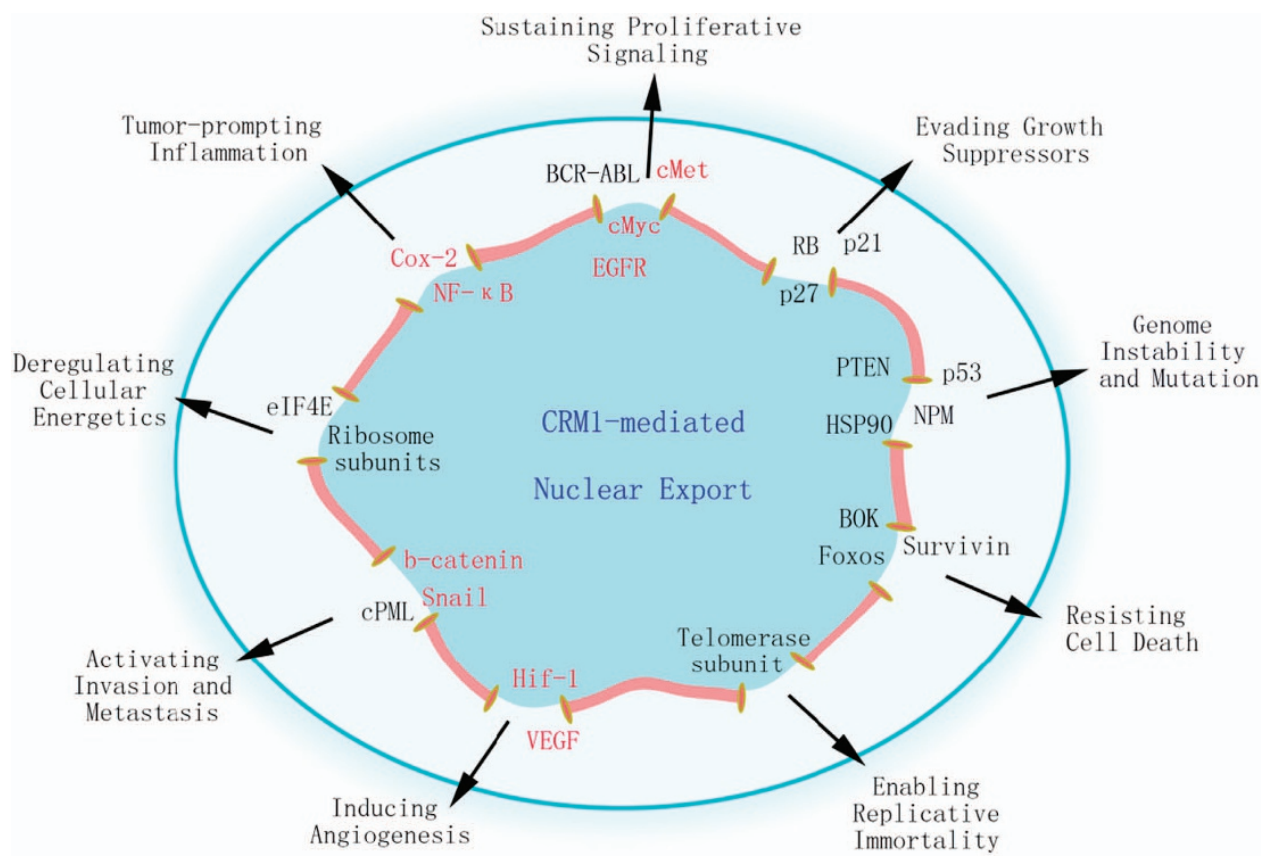

Figure 2. CRM1-mediated nuclear export and cancer hallmarks. CRM1 contributes to the different aspects of cancer hallmarks and CRM1 inhibition may downregulate 9 out of 10 cancer hallmark processes simultaneously. Proteins in black are direct cargoes of CRM1, which are mislocalized to the cytoplasm in various cancer cells. Proteins in red may not be direct cargoes of CRM1, but are shown to be suppressed by nuclear export inhibition through different mechanisms.

protein, p21 and p27. ${ }^{75}$ These cell cycle inhibitors function in the nucleus in normal cells, but are mislocalized to the cytoplasm by CRM1 in various cancers. ${ }^{84-86}$ For example, p27 is a tumor suppressor that functions in the nucleus to inhibit G1 progression in normal cells. ${ }^{87}$ In tumor cells it is rarely mutated, but rather aberrantly exported to the cytoplasm by CRM1, where it is degraded by the proteasome or functions as an oncogene by promoting cell migration. ${ }^{88-90}$ CRM1 inhibition significantly increases nuclear p27 levels and decreases the cytoplasmic oncogenic pool of this protein (Ser10 phosphorylated p27) in tumor cells. $53,90,91$

\section{Genome instability and mutation}

In cancer cells, the DNA maintenance machinery is often mutated or mislocalized, thereby facilitating alterations of the genome and the acquisition of multiple hallmarks subsequently. ${ }^{75}$ p53 is a wellknown genome guardian, which has pivotal roles in sensing and repairing DNA damage. ${ }^{92}$ Besides $\mathrm{p} 53$ mutations, cancer cells can evade p53 survillience through CRM1-mediated p53 nuclear export. ${ }^{93,94}$ Treatment with CRM1 inhibitors results in increased nuclear p53 level, triggering p53-mediated transcription and apoptosis. ${ }^{58,95}$ Similarly, several other proteins critical for genome stability are exported to the cytoplasm in different types of cancer cells, including HSP90, nucleophosmin and PTEN. ${ }^{96-98}$

Resisting cell death

In addition to the sustained proliferation ability, cancer cells must bypass programmed cell death by apoptosis. ${ }^{75}$ Survivin, a member of the inhibitor of apoptosis family, is localized in both the nucleus and the cytoplasm of tumor cells, and it is the cytosolic fraction that exerts the cancer-promoting activity. ${ }^{99,100}$ Inhibition of nuclear export by survivin NES antibodies promotes the nuclear accumulation and degradation of survivin, which abolishes its cytoprotective function. ${ }^{101,102}$ In another study, nuclear accumulation of pro-apoptotic protein Bok (Bcl-2-related ovarian killer) by mutation of its NES or CRM1 inhibition causes apoptosis in breast cancer cells. ${ }^{103}$ Another example pertains to FOXO family proteins, which are important transcription factors controlling the expression of apoptosis-related genes. ${ }^{104}$ Through phosphorylation events, their NESs are exposed, leading to FOXO's cytoplasmic localization and loss of pro-apoptotic activity in cancer cells. ${ }^{18}$

Enabling replicative immortality

Maintenance of telomeres by telomerase is important for chromosome stabilization and cell immortalization. ${ }^{105}$ As such, telomerase is activated in germ cells and most cancers. ${ }^{106}$ Telomerase RNA subunit TLC1 must be exported into the cytoplasm to recruit the protein subunits for complete assembly of the enzyme, which is then imported into the nucleus to extend telomeres. ${ }^{107}$ Nuclear export of TLC1 requires both CRM1 and the messenger RNA export machinery. ${ }^{108}$ It is reported that nuclear export of TLC1 is an essential step for the formation of the functional RNA containing enzyme, and blocking TLC1 export prevents its cytoplasmic maturation and leads to telomere shortening. ${ }^{108}$

\section{Inducing angiogenesis}

Tumor growth requires new blood vessels formation to supply nutrients for increasing mass of tumor cells. ${ }^{109}$ The well-known prototype of angiogenesis inducer is vascular endothelial growth factor. ${ }^{110}$ CRM1 inhibition causes nuclear retention of the NEScontaining cargo Fbw7, a subunit of a ubiquitin ligase that promotes the degradation of nuclear Notch-1 and further leads to decreased vascular endothelial growth factor level. ${ }^{66}$ Copper metabolism MURR1 domain 1 (COMMD1) protein, an inhibitor of HIF-1, is actively exported to the cytoplasm by CRM1 under low oxygen concentrations. ${ }^{111}$ Disruption of the NESs or CRM1 inhibition results in nuclear accumulation of COMMD1, enhancing the repression of transcriptional activity of HIF-1 by COMMD1. ${ }^{11}$

\section{Activating invasion and metastasis}

The transcription factor Snail has important roles in epithelialmesenchymal transition, tumor invasion and metastasis. ${ }^{12}$ CRM1 
inhibition leads to nuclear accumulation of FBXL5 (F-Box and leucine-rich repeat protein 5), which is a negative regulator of Snail. ${ }^{113}$ Silencing CRM1 or Snail results in nuclear accumulation of FBXL5 and inhibition of epithelial-mesenchymal transition. ${ }^{113}$ Similarly, APC (adenomatous polyposis coli) protein, a negative regulator of nuclear $\beta$-catenin, is mislocalized to the cytoplasm by CRM1 in cancer cells, resulting in uncontrolled $\beta$-catenin transactivation of metastasis-related proteins. ${ }^{40,114}$ Further, cytoplasmic promyelocytic leukemia (CPML) promotes a mesenchymal phenotype and increases the invasiveness of prostate cancer cells through transforming growth factor- $\beta$ signaling. ${ }^{115} \mathrm{CPML}$ nuclear export is mediated by CRM1, co-expression of which with CPML correlates with reduced disease-specific survival in patients. ${ }^{115}$

Deregulating cellular energetics

Cancer cells usually display upregulated energetic metabolism to adapt to their high rate of proliferation. ${ }^{75}$ The ribosome is an effective cancer drug target because ribosome inhibition limits cellular energetics by affecting global protein synthesis. ${ }^{116,117}$ CRM1-mediated nuclear export is essential for nuclear export of pre-mature ribosome subunits and inhibition of CRM1 causes immature $40 \mathrm{~S}$ and $60 \mathrm{~S}$ ribosome production. ${ }^{118-120}$ In addition to ribosome biogenesis, hyperactive translation via eukaryotic translation initiation factor elF4E is common in the majority of cancers. ${ }^{121}$ elF4E is abnormally exported to the cytoplasm by CRM1 in cancer cells, together with several proliferative messenger RNAs. ${ }^{122}$ elF4E cytoplasmic localization in leukemia patients strongly correlates with elF4E inhibitor treatment outcome. ${ }^{123}$

Tumor-promoting inflammation

The importance of inflammation in tumor development has been increasingly recognized. ${ }^{124}$ Cox- 2 and NF-KB are the key cellular mediators of inflammation that are often upregulated in cancer cells. $^{125,126}$ It is shown that CRM1 inhibitor downregulates Cox-2 level by limiting its messenger RNA export. ${ }^{72}$ Treatment of ovarian cancer cells with a CRM1 inhibitor revealed a reduction in COX-2 expression and concomitant reduction of cell proliferation and increased apoptosis. ${ }^{47} \mathrm{NF}-\mathrm{KB}$ inhibitor $\mathrm{IKBa}_{\mathrm{K}}$ is also a cargo of CRM $1 .{ }^{127}$ IKBa is rapidly locked in the nucleus by CRM1 inhibition and forms a transcriptional inactive complex with NF-KB. ${ }^{128,129}$

Although it is impossible to summarize all proteins involved in nuclear export and cancer, the above examples clearly illustrate the strong link between CRM1 inhibition and reversion of cancer hallmarks. Many mechanism-based cancer drugs only target one particular aspect of cancer. For instance, epidermal growth factor receptor inhibitors reduce cancer proliferation, CDK inhibitors stop cell cycle and $\mathrm{BH} 3$ mimetics promote cell death. ${ }^{130-132}$ In response to such single-target therapy, cancer cells may reduce their reliance on a particular protein and develop more dependence on another. ${ }^{75,133}$ Importantly, CRM1-mediated nuclear export is a significant contributing factor in the development of drug resistance. ${ }^{70,134,135}$ As CRM1 inhibition could downregulate 9 out of 10 cancer features simultaneously, it probably would be more effective than targeting a single pathway. Indeed, it has been observed that CRM1 inhibitors have broad-spectrum anti-cancer potency in pre-clinical and clinical studies.

\section{DIFFERENT CLASSES OF NUCLEAR EXPORT INHIBITORS}

Over the past two decades, plenty of nuclear export inhibitors (NEls) have been discovered or developed, tested against diseases such as cancer, virus infection and neuronal degeneration. ${ }^{2,41,134}$ By their origins, these inhibitors can be classified into four groups as follows: bacterial products, herbal ingredients, fungal or animal NEls, and synthetic NEls (Figure 3). (1) Bacterial NEls include leptomycin $A / B$, ratjadone $A / C$ and anguinomycin $A / B / C / D$, which all have a long polyketide chain with a lactone ring. ${ }^{136-138}$ In general, they are very potent against cancer cells (half-maximal inhibitory concentration below $10 \mathrm{~nm}$ ), but too toxic and profiling very narrow therapeutic window. ${ }^{136-138}$ (2) Several plant NEls were discovered from South/Southeast Asia herbs and food additives in a

Bacterial products
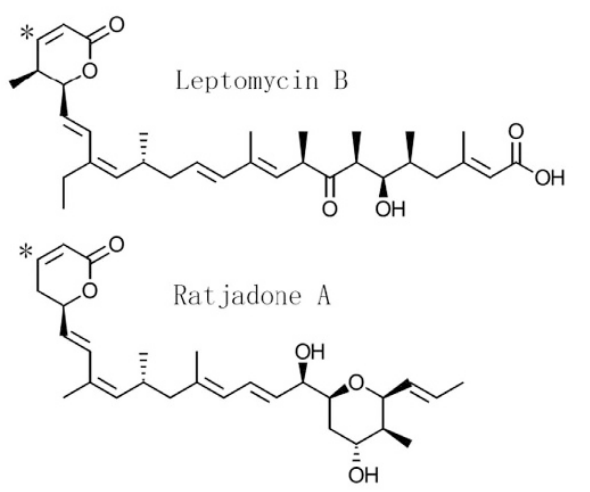

d

Synthetic NEIs<smiles>CC1=C(COCCC(C)(C)C)[C@H](C(=O)NNc2ccc(C(F)(F)F)c(Cl)n2)C(=O)C1=O</smiles><smiles>O=C(/C=C\n1cnc(-c2cc(C(F)(F)F)cc(C(F)(F)F)c2)n1)NNc1cnccn1</smiles>

b

Plant ingredients<smiles>O=C1C=CC[C@H](/C=C/c2ccccc2)O1</smiles>

Goniothalamin

Fungal/animal NEIs<smiles>CCCC/C=C/C=C1/C(=O)C=C[C@H]1C/C=C/CCCC(=O)O</smiles>

15d-PGJ2

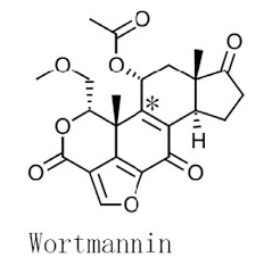

Wortmannin<smiles>CC1=CC(=O)c2c(O)cccc2C1=O</smiles>

Plumbagin

Figure 3. Four classes of nuclear export inhibitors (NEls). Two representative NEls from each class is drawn, including (a) bacterial products leptomycin B and ratjadone $A$; (b) plant ingredients goniothalamin and plumbagin; (c) wortmannin from fungus and 15d-PGJ2 from animals; (d) synthetic NEls CBS9106 and KPT-330. Asterisk $(*)$ denotes possible covalent binding sites to Cys528 on CRM1. 
recent years, including valtrate, oridonin, acetoxychavicol acetate, curcumin, gonionthalamin, piperlongumine and plumbagin. ${ }^{62,139-144}$ Plant NEls generally bind/inhibit CRM1 poorly and display mild anti-tumor activity. ${ }^{62,139-144}$ (3) Wortmannin and cyclopentenone prostaglandin (15d-PGJ2) were known for other functions before they were discovered as CRM1 inhibitors. ${ }^{145,146}$ Fungal steroid metabolite wortmannin is a well-known PI3K inhibitor. ${ }^{147}$ The cyclopentenone prostaglandin $15 \mathrm{~d}-\mathrm{PGJ} 2$ is an anti-inflammatory compound produced in the body. ${ }^{148}$ They both have low micromolar NES inhibition potency, which may explain their anti-proliferative and anti-inflammatory properties known earlier. $^{145,149}$ (4) Realizing the significance of NEI in the treatment of cancers and other diseases, scientists have discovered a variety of synthetic inhibitors, including PKF050-638, 5219668, SINEs, compound3/4, CBS9106 and S109. ${ }^{6,48,145,150-153}$ CBS9106 has antitumor effect as a single agent in 60 different human cancer cell lines at sub-micromolar concentrations. ${ }^{154}$ SINEs are currently undergoing over 40 clinical trials, for human hematologic malignances and solid tumors (https://clinicaltrial.gov/).

It should be noted that all these inhibitors form a covalent bond with Cys528 of human CRM1 protein, through a Michael addition reaction. Cys528 lies in the NES-binding groove of CRM1 (Figures $4 a$ and b). Thus, these inhibitors directly inhibit NES binding to CRM1 (Figures 4c and d). Mutation of Cys528 disables the anti-tumor action of these compounds. ${ }^{48,62,70,113,151,152,155}$ Next, we will focus on two classes of the most characterized NEls: LMB and SINEs.

\section{FIRST-GENERATION NEI: LMB}

The first and most well-known inhibitor of CRM1 is LMB. ${ }^{156}$ LMB is a natural product produced by bacteria Streptomyces. ${ }^{157}$ It was first identified as an anti-fungal agent. ${ }^{158}$ Later on, it is discovered that LMB potently kills cancer cells. ${ }^{159}$ Scientists had proved that CRM1 is the cellular target of LMB as early as 1998; however, the LMBCRM1 complex structure was not solved until recently. ${ }^{160,161}$

$\mathrm{LMB}$ is a long polyketide molecule with an $\alpha, \beta$-unsaturated lactone warhead (Figure 3). In complex with CRM1, its long polyketide chain aligns with the hydrophobic NES-binding groove, forming extensive hydrophobic interactions (Figure 4c). The $a, \beta-$ unsaturated lactone warhead links to a Cys528 equivalent residue of yeast CRM1 at a-position (Figure 4e). Unexpectedly, the lactone ring of LMB is hydrolyzed, forming an opened up structure of hydroxy acid (Figure 4e). The same hydrolysis is also observed in two other CRM1 inhibitors (anguinomycin A and ratjadone A) from bacteria. ${ }^{161}$ After hydrolysis, LMB forms extra interactions with CRM1, gaining one salt bridge and one hydrogen bond with CRM1. ${ }^{161}$ The hydrolysis is caused by three basic residues (in CRM1) adjacent to the LMB lactone ring, mutation of which results in CRM1 mutant that does not hydrolyze LMB's lactone ring. ${ }^{161}$

LMB lactone hydrolysis leads to an unexpected finding that the covalent bond between LMB and CRM1 is reversible under certain condition. Using dialysis and pull-down assay, it is shown that LMB with lactone ring de-conjugates from CRM1 (slowly), whereas the hydrolyzed LMB does not. ${ }^{161}$ Thus, hydrolysis prevents de-conjugation of inhibitor and increases inhibitor potency. A permanent CRM1 inhibitor could provide Streptomyces bacteria more space to grow by killing fungi more efficiently, as CRM1mediated nuclear export pathway is essential for fungi. ${ }^{1}$ More importantly, this finding could also explain the clinically strong cytotoxicity of LMB. LMB entered clinical trial for the treatment of cancers in 1996. ${ }^{136}$ However, strong dosage-limiting toxicities produced barely any clinical benefits and the mechanism of toxicity was unknown at the time. ${ }^{136}$ Indeed, recent studies also show that LMB-treated cells have permanently blocked nuclear export, which is lethal not only for cancer cells, but also for normal cells. ${ }^{1,48,155}$

\section{SECOND-GENERATION NEI: SINE}

Although the early clinical failure of LMB spelled doom for CRM1targeted drug development, it did not stop the endeavor of academic and pharmaceutical researchers, who discovered NEls with improved pharmacological properties through library screens, of which PKF050-638 was found as an anti-viral hit. ${ }^{150}$ Its $N$-azolylacrylate scaffold is later on adopted by SINEs. ${ }^{2}$

Like LMB, SINEs also form covalent bond with Cys528 of CRM1. However, SINEs differ from LMB in several aspects (Table 1). ${ }^{162}$ First, SINEs are much more compact when compared with LMB. Whereas LMB occupies almost the entire NES groove, smaller SINEs occupies $<50 \%$ of the space (Figure $4 d$ ). Second, in contrast to LMB, KPT-185 (one of the SINEs) is not hydrolyzed after binding to CRM1 and does not form salt bridge with CRM1 (Figure 4f). ${ }^{56,163,164}$ As such, its covalent bond to CRM1 is found to
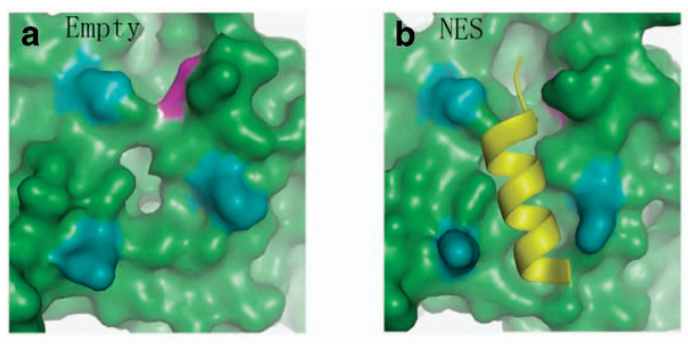

e

LMB conjugation

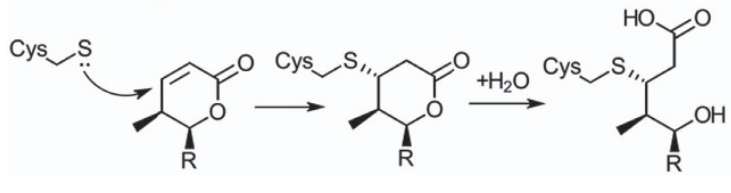

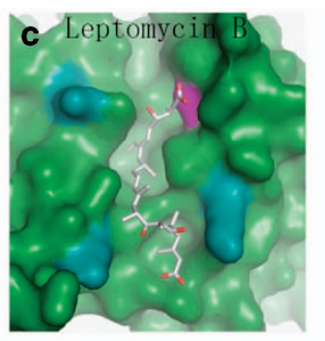

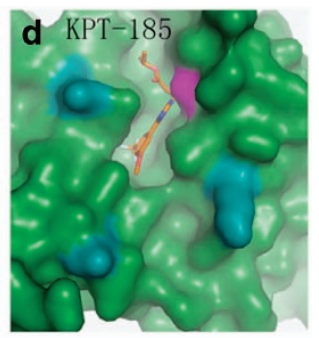

f KPT-185 conjugation

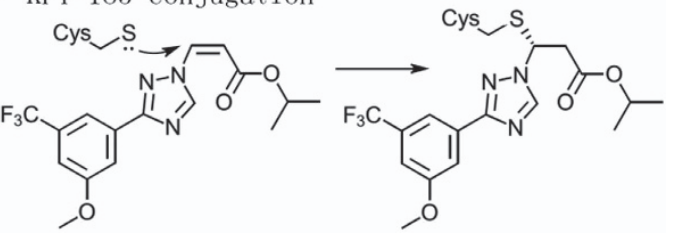

Figure 4. Binding of CRM1 by different molecules. CRM1's NES-binding grove in the empty (a), NES-bound (b), leptomycin B-bound (c) and KPT-185-bound (d) states is shown in green surface representation. The pdb codes are 4HB2, 3GB8, 4HAT and 4GMX respectively. Cys528 is highlighted in purple. NES, LMB and KPT-185 are colored yellow, tint and brown respectively. Three aligned residues are colored cyan to illustrate the orientation of NES groove. (e) Mechanism of LMB conjugation. R resembles the long polyketide chain. (f) Mechanism of KPT-185 conjugation. 
Table 1. Comparison of LMB and KPT-330's properties

\begin{tabular}{lll}
\hline & LMB & KPT-330 \\
\hline Covalent binding & Yes & Yes \\
Hydrolysis reaction & Yes & No \\
Covalent bond reversibility & No & Yes \\
CRM1 degradation & No & Yes \\
CRM1 regeneration & No & Yes \\
Cellular nuclear export inhibition & Permanent & Transient \\
Toxicity & High & Low \\
\hline
\end{tabular}

Abbreviation: $L M B$, leptomycin $B$. LMB results in permanent nuclear export inhibition, whereas KPT-330 induces transient nuclear export inhibition. Although LMB is cinilically highly toxicic, KPT-330 displays much reduced toxicity and is currently undergoing over 40 human clinical trials.

be slowly reversible. ${ }^{161}$ Third, SINEs but not LMB treatment induces CRM1 degradation, followed by CRM1 re-synthesis after drug removal. ${ }^{59,165}$ Therefore, through bond reversibility and re-synthesis, nuclear export inhibition by SINE treatment is not permanent, but rather transient. It is found that nuclear export in KPT-treated mouse at $10 \mathrm{mg} \mathrm{kg}^{-1}$ reversed to $\sim 20 \%$ after 1 day and $50 \%$ after 3 days. ${ }^{155}$ These observations altogether could explain the fact that SINE is significantly less toxic than LMB observed in clinical trials.

Reported SINEs include KPT-185, KPT-249, KPT-251, KPT-276, KPT-330 and KPT-335. Their half-maximal effective concentration for cancer cells lies between $10 \mathrm{~nm}$ to $1 \mu \mathrm{m}$, and 5-20 $\mu \mathrm{m}$ for nonneoplastic cells. ${ }^{133}$ KPT-185 is the most studied compound, with limited bioavailability in murine and monkey pharmacokinetic studies. $^{95}$ KPT-276 has been shown to block inflammation and nerve cell damage in mouse models of inflammatory demyelination. ${ }^{164}$ KPT-335 has received a Minor Use/Minor Species designation from the Center for Veterinary Medicine of the Food and Drug Administration for the treatment of lymphomas in canines.

Of all the SINEs, KPT-330 (Selinexor) is the most promising compound and is undergoing numerous human hematologic and solid tumor clinical trials. Before KPT-330's clinical trial, many expected that inhibiting nuclear export will generate profound side effects, as CRM1 is essential for viability and maintaining the proper localizations of its target cargoes required for normal functions of the cell. ${ }^{1,166,167}$ However, side effects of SINE observed are much milder and controllable, including nausea, vomiting, anorexia, diarrhea, fatigue, weight loss and hepatotoxicity, by no means comparable to chemotherapy treatment. ${ }^{133,168,169}$ The efficacy and toxicity of SINE compounds were reviewed elsewhere recently. $6,63,69,170$

\section{FUTURE PERSPECTIVE: NON-COVALENT NEIS}

To our best knowledge, all known NEls are covalent CRM1 inhibitors and rely on the conserved Cys528 residue on CRM1 to exert its therapeutic effects. Mutation of Cys528 renders current CRM1 inhibitors inactive. ${ }^{62,113,155,171,172}$ Interestingly, Cys528 mutation has been found in a huge number of fungal CRM1, which provides resistance to the anti-fungal agent LMB. ${ }^{17}$ Here we would like to propose a different class of NEl: non-covalent NEI. Non-covalent NEls can be used in various cancers like their covalent counterparts by exerting transient inhibition, yet being insensitive to Cys528 mutation. In addition, they may possess intrinsically lower toxicity and higher efficacy.

The majority of drugs in clinical use are non-covalent in nature. ${ }^{173}$ Generally, covalent inhibitors are more prone to nonspecific conjugation and causing undesirable off-target effects. ${ }^{174,175}$ All the current NEls have a Michael acceptor, which is mild reactive and could bind to various targets. ${ }^{148,161,176}$ Side effects of SINE are mainly gastrointestinal and liver related. ${ }^{168,177,178}$ As SINE compounds are taken orally, its higher gastrointestinal concentration may result in more local off-target covalent binding, possibly accounting for the observed side effects.

In addition, SINE resistance can occur in tumor cells expressing very high level of CRM1, and in cells that tumor suppressor proteins are relocalized to cytoplasm after SINE treatment. ${ }^{155,178,179}$ With reduced side effects, non-covalent NEI could be used at higher dosage to achieve tighter transient inhibition, to increase its anti-tumor activity and to improve response rate in patients.

\section{CONCLUSION}

Cancer is not a single disease, as many different pathways are activated in different cancer cells. Nuclear export factor CRM1 exports/regulates many tumor suppressors and oncoproteins. Notably, CRM1 inhibition can attenuate many cancer hallmarks simultaneously, likely explaining the broad-spectrum anti-cancer potencies observed. The first-generation NEI LMB failed in phase I clinical trial due to high cytotoxicity. Second-generation inhibitors display much reduced cytotoxicity, owing to its reversible inhibition of nuclear export. It should be emphasized that 'broad-spectrum' anti-cancer does not imply 'all-spectrum', in other words-effective against all cancers. Although KPT-330 clinical trials have been very encouraging, non-covalent NEls remain an interesting alternative for its possibly low-toxicity and broad-spectrum action as a CRM1targeted anti-cancer therapy.

\section{ACKNOWLEDGEMENTS}

We thank Drs Yuh Min Chook (UTSW) and Chong Chen (SKLB) for comments. QS is supported by National Natural Science Foundation of China (NSFC), fund number 80502629. EB is supported by NIH R01-DK073639 and CPRIT grants. DJ is a 'Junior One Thousand Talents' program scholar. We apologize for those relavent works overlooked by this review.

\section{COMPETING INTERESTS}

The authors declare no conflict of interest.

\section{REFERENCES}

1 Stade K, Ford CS, Guthrie C, Weis K. Exportin $1(\mathrm{Crm} 1 \mathrm{p})$ is an essential nuclear export factor. Cell 1997; 90: 1041-1050.

2 Gravina GL, Senapedis W, McCauley D, Baloglu E, Shacham S, Festuccia C. Nucleo-cytoplasmic transport as a therapeutic target of cancer. J Hematol Oncol 2014; 7: 85

3 Takeda A, Yaseen NR. Nucleoporins and nucleocytoplasmic transport in hematologic malignancies. Semin Cancer Biol 2014; 27: 3-10.

4 Hing ZA, Mantel R, Beckwith KA, Guinn D, Williams E, Smith LL et al. Selinexor is effective in acquired resistance to ibrutinib and synergizes with ibrutinib in chronic lymphocytic leukemia. Blood 2015; 125: 3128-3132.

5 Khorashad JS, Eiring AM, Mason CC, Gantz KC, Bowler AD, Redwine HM et al. shRNA library screening identifies nucleocytoplasmic transport as a mediator of BCR-ABL1 kinase-independent resistance. Blood 2015; 125: 1772-1781.

6 Senapedis WT, Baloglu E, Landesman Y. Clinical translation of nuclear export inhibitors in cancer. Semin Cancer Biol 2014; 27: 74-86.

7 Cook A, Bono F, Jinek M, Conti E. Structural biology of nucleocytoplasmic transport. Annu Rev Biochem 2007; 76: 647-671.

8 Schmidt HB, Gorlich D. Transport selectivity of nuclear pores, phase separation, and membraneless organelles. Trends Biochem Sci 2016; 41: 46-61.

9 Gorlich D, Mattaj IW. Nucleocytoplasmic transport. Science 1996; 271: 1513-1518.

10 Ullman KS, Powers MA, Forbes DJ. Nuclear export receptors: from importin to exportin. Cell 1997; 90: 967-970.

11 Fried H, Kutay U. Nucleocytoplasmic transport: taking an inventory. Cell Mol Life Sci 2003; 60: 1659-1688.

12 Tran EJ, Bolger TA, Wente SR. SnapShot: nuclear transport. Cell 2007; 131: 420.

13 Chook YM, Suel KE. Nuclear import by karyopherin-betas: recognition and inhibition. Biochim Biophys Acta 2011; 1813: 1593-1606. 
14 Weis K. Importins and exportins: how to get in and out of the nucleus. Trends Biochem Sci 1998; 23: 185-189.

15 Lee BJ, Cansizoglu AE, Suel KE, Louis TH, Zhang Z, Chook YM. Rules for nuclear localization sequence recognition by karyopherin beta 2. Cell 2006; 126: 543-558.

16 Tran EJ, King MC, Corbett AH. Macromolecular transport between the nucleus and the cytoplasm: Advances in mechanism and emerging links to disease. Biochim Biophys Acta 2014; 1843: 2784-2795.

17 Yashiroda Y, Yoshida M. Nucleo-cytoplasmic transport of proteins as a target for therapeutic drugs. Curr Med Chem 2003; 10: 741-748.

18 Vogt PK, Jiang $\mathrm{H}$, Aoki M. Triple layer control: phosphorylation, acetylation and ubiquitination of FOXO proteins. Cell Cycle 2005; 4: 908-913.

19 Craig E, Zhang ZK, Davies KP, Kalpana GV. A masked NES in INI1/hSNF5 mediates hCRM1-dependent nuclear export: implications for tumorigenesis. EMBO J 2002 21: 31-42.

20 Pichler A, Melchior F. Ubiquitin-related modifier SUMO1 and nucleocytoplasmic transport. Traffic 2002; 3: 381-387.

21 Grisendi S, Mecucci C, Falini B, Pandolfi PP. Nucleophosmin and cancer. Nat Rev Cancer 2006; 6: 493-505.

22 Conti E, Uy M, Leighton L, Blobel G, Kuriyan J. Crystallographic analysis of the recognition of a nuclear localization signal by the nuclear import factor karyopherin alpha. Cell 1998; 94: 193-204

23 Cingolani G, Petosa C, Weis K, Muller CW. Structure of importin-beta bound to the IBB domain of importin-alpha. Nature 1999; 399: 221-229.

24 Gorlich D. Transport into and out of the cell nucleus. EMBO J 1998; 17: 2721-2727.

25 Chook YM, Blobel G. Structure of the nuclear transport complex karyopherinbeta2-Ran x GppNHp. Nature 1999; 399: 230-237.

26 Lui K, Huang Y. RanGTPase: a key regulator of nucleocytoplasmic trafficking. Mol Cell Pharmacol 2009; 1: 148-156.

27 Bischoff FR, Klebe C, Kretschmer J, Wittinghofer A, Ponstingl H. RanGAP1 induces GTPase activity of nuclear Ras-related Ran. Proc Natl Acad Sci USA 1994; 91 2587-2591.

28 Monecke T, Guttler T, Neumann P, Dickmanns A, Gorlich D, Ficner R. Crystal structure of the nuclear export receptor CRM1 in complex with Snurportin1 and RanGTP. Science 2009; 324: 1087-1091.

29 Dong X, Biswas A, Chook YM. Structural basis for assembly and disassembly of the CRM1 nuclear export complex. Nat Struct Mol Biol 2009; 16: 558-560.

30 Dong X, Biswas A, Suel KE, Jackson LK, Martinez R, Gu H et al. Structural basis for leucine-rich nuclear export signal recognition by CRM1. Nature 2009; 458: 1136-1141.

31 Koyama M, Matsuura Y. An allosteric mechanism to displace nuclear export cargo from CRM1 and RanGTP by RanBP1. EMBO J 2010; 29: 2002-2013.

32 Grunwald M, Lazzaretti D, Bono F. Structural basis for the nuclear export activity of Importin13. EMBO J 2013; 32: 899-913.

33 Grunwald M, Bono F. Structure of Importin13-Ubc9 complex: nuclear import and release of a key regulator of sumoylation. EMBO J 2011; 30: 427-438.

34 Cullen BR. Nuclear mRNA export: insights from virology. Trends Biochem Sci 2003; 28: 419-424.

35 Ossareh-Nazari B, Bachelerie F, Dargemont C. Evidence for a role of CRM1 in signal-mediated nuclear protein export. Science 1997; 278: 141-144.

36 Delaleau M, Borden KL. Multiple export mechanisms for mRNAs. Cells 2015; 4 452-473.

$37 \mathrm{Xu} \mathrm{D}$, Grishin NV, Chook YM. NESdb: a database of NES-containing CRM1 cargoes. Mol Biol Cell 2012; 23: 3673-3676.

38 la Cour T, Kiemer L, Molgaard A, Gupta R, Skriver K, Brunak S. Analysis and prediction of leucine-rich nuclear export signals. Protein Eng Des Sel 2004; 17: 527-536

39 Fu SC, Huang HC, Horton P, Juan HF. ValidNESs: a database of validated leucinerich nuclear export signals. Nucleic Acids Res 2013; 41: D338-D343.

40 Kirli K, Karaca S, Dehne HJ, Samwer M, Pan KT, Lenz C et al. A deep proteomics perspective on CRM1-mediated nuclear export and nucleocytoplasmic partitioning. elife 2015; 4: e11466.

41 Mao L, Yang Y. Targeting the nuclear transport machinery by rational drug design. Curr Pharm Design 2013; 19: 2318-2325.

42 Yedavalli VS, Neuveut C, Chi YH, Kleiman L, Jeang KT. Requirement of DDX3 DEAD box RNA helicase for HIV-1 Rev-RRE export function. Cell 2004; 119 381-392.

43 Gao W, Lu C, Chen L, Keohavong P. Overexpression of CRM1: a characteristic feature in a transformed phenotype of lung carcinogenesis and a molecular target for lung cancer adjuvant therapy. J Thorac Oncol 2015; 10: 815-825.

44 Yao Y, Dong Y, Lin F, Zhao H, Shen Z, Chen P et al. The expression of CRM1 is associated with prognosis in human osteosarcoma. Oncol Rep 2009; 21: 229-235.
45 Shen A, Wang Y, Zhao Y, Zou L, Sun L, Cheng C. Expression of CRM1 in human gliomas and its significance in p27 expression and clinical prognosis. Neurosurgery 2009; 65: 153-159; discussion 159-160.

46 Huang WY, Yue L, Qiu WS, Wang LW, Zhou XH, Sun YJ. Prognostic value of CRM1 in pancreas cancer. Clin Invest Med 2009; 32: E315.

47 Noske A, Weichert W, Niesporek S, Roske A, Buckendahl AC, Koch I et al. Expression of the nuclear export protein chromosomal region maintenance/ exportin 1/Xpo1 is a prognostic factor in human ovarian cancer. Cancer 2008; 112: $1733-1743$

48 Liu X, Chong Y, Liu H, Han Y, Niu M. Novel reversible selective inhibitor of CRM1 for targeted therapy in ovarian cancer. J Ovarian Res 2015; 8: 35.

49 van der Watt PJ, Maske CP, Hendricks DT, Parker MI, Denny L, Govender D et al. The Karyopherin proteins, Crm1 and Karyopherin beta1, are overexpressed in cervical cancer and are critical for cancer cell survival and proliferation. Int $J$ Cancer 2009; 124: 1829-1840.

50 Inoue H, Kauffman M, Shacham S, Landesman Y, Yang J, Evans CP et al. CRM1 blockade by selective inhibitors of nuclear export attenuates kidney cancer growth. J Urol 2013; 189: 2317-2326.

51 van der Watt PJ, Zemanay W, Govender D, Hendricks DT, Parker MI, Leaner VD. Elevated expression of the nuclear export protein, $\mathrm{Crm} 1$ (exportin 1), associates with human oesophageal squamous cell carcinoma. Oncol Rep 2014; 32: 730-738.

52 Zhou F, Qiu W, Yao R, Xiang J, Sun X, Liu S et al. CRM1 is a novel independent prognostic factor for the poor prognosis of gastric carcinomas. Med Oncol 2013; 30: 726 .

53 Zheng Y, Gery S, Sun H, Shacham S, Kauffman M, Koeffler HP. KPT-330 inhibitor of XPO1-mediated nuclear export has anti-proliferative activity in hepatocellular carcinoma. Cancer Chemoth Pharm 2014; 74: 487-495.

54 Kojima K, Kornblau SM, Ruvolo V, Dilip A, Duvvuri S, Davis RE et al. Prognostic impact and targeting of CRM1 in acute myeloid leukemia. Blood 2013; 121: 4166-4174.

55 Conway AE, Haldeman JM, Wechsler DS, Lavau CP. A critical role for CRM1 in regulating HOXA gene transcription in CALM-AF10 leukemias. Leukemia 2015; 29: 423-432.

56 Lapalombella R, Sun Q, Williams K, Tangeman L, Jha S, Zhong Y et al. Selective inhibitors of nuclear export show that CRM1/XPO1 is a target in chronic lymphocytic leukemia. Blood 2012; 120: 4621-4634.

57 Zhang K, Wang M, Tamayo AT, Shacham S, Kauffman M, Lee J et al. Novel selective inhibitors of nuclear export CRM1 antagonists for therapy in mantle cell lymphoma. Exp Hematol 2013; 41: 67-78 e64.

58 Yoshimura M, Ishizawa J, Ruvolo V, Dilip A, Quintas-Cardama A, McDonnell TJ et al. Induction of p53-mediated transcription and apoptosis by exportin-1 (XPO1) inhibition in mantle cell lymphoma. Cancer Sci 2014; 105: 795-801.

59 Tai YT, Landesman Y, Acharya C, Calle Y, Zhong MY, Cea M et al. CRM1 inhibition induces tumor cell cytotoxicity and impairs osteoclastogenesis in multiple myeloma: molecular mechanisms and therapeutic implications. Leukemia 2014; 28: $155-165$

60 Schmidt J, Braggio E, Kortuem KM, Egan JB, Zhu YX, Xin CS et al. Genome-wide studies in multiple myeloma identify XPO1/CRM1 as a critical target validated using the selective nuclear export inhibitor KPT-276. Leukemia 2013; 27: 2357-2365.

61 Boons E, Vanstreels E, Jacquemyn M, Nogueira TC, Neggers JE, Vercruysse T et al. Human exportin-1 is a target for combined therapy of HIV and AIDS related lymphoma. EBioMedicine 2015; 2: 1102-1113.

62 Niu M, Xu X, Shen Y, Yao Y, Qiao J, Zhu F et al. Piperlongumine is a novel nuclear export inhibitor with potent anticancer activity. Chem Biol Interact 2015; 237: 66-72.

63 Ishizawa J, Kojima K, Hail Jr N, Tabe Y, Andreeff M. Expression, function, and targeting of the nuclear exporter chromosome region maintenance 1 (CRM1) protein. Pharmacol Ther 2015; 153: 25-35.

64 Green AL, Ramkissoon SH, McCauley D, Jones K, Perry JA, Hsu JH et al. Preclinical antitumor efficacy of selective exportin 1 inhibitors in glioblastoma. Neuro Oncol 2015; 17: 697-707.

65 Yang X, Cheng L, Yao L, Ren H, Zhang S, Min X et al. Involvement of chromosome region maintenance 1 (CRM1) in the formation and progression of esophageal squamous cell carcinoma. Med Oncol 2014; 31: 155.

66 Gao J, Azmi AS, Aboukameel A, Kauffman M, Shacham S, Abou-Samra AB et al. Nuclear retention of Fbw7 by specific inhibitors of nuclear export leads to Notch1 degradation in pancreatic cancer. Oncotarget 2014; 5: 3444-3454.

67 Wang DL, Wang YC, Lu P, E Q, Shi GS. [Expression of nuclear export factor CRM1 and p27 in glioma]. Zhonghua Bing Li Xue Za Zhi 2008; 37: 454-457.

68 Gerecitano J. SINE (selective inhibitor of nuclear export) - translational science in a new class of anti-cancer agents. $J$ Hematol Oncol 2014; 7: 67.

69 Mendonca J, Sharma A, Kim HS, Hammers H, Meeker A, De Marzo A et al. Selective inhibitors of nuclear export (SINE) as novel therapeutics for prostate cancer. Oncotarget 2014; 5: 6102-6112. 
70 Turner JG, Dawson J, Cubitt CL, Baz R, Sullivan DM. Inhibition of CRM1dependent nuclear export sensitizes malignant cells to cytotoxic and targeted agents. Semin Cancer Biol 2014; 27: 62-73.

71 De Cesare M, Cominetti D, Doldi V, Lopergolo A, Deraco M, Gandellini P et al. Anti-tumor activity of selective inhibitors of XPO1/CRM1-mediated nuclear export in diffuse malignant peritoneal mesothelioma: the role of survivin. Oncotarget 2015; 6: 13119-13132.

72 Jang BC, Munoz-Najar U, Paik JH, Claffey K, Yoshida M, Hla T. Leptomycin B an inhibitor of the nuclear export receptor CRM1, inhibits COX-2 expression. J Biol Chem 2003; 278: 2773-2776.

73 Sakuma T, Nakagawa T, Ido K, Takeuchi H, Sato K, Kubota T. Expression of vascular endothelial growth factor-A and mRNA stability factor HuR in human meningiomas. J Neurooncol 2008; 88: 143-155.

74 Hanahan D, Weinberg RA. The hallmarks of cancer. Cell 2000; 100: 57-70.

75 Hanahan D, Weinberg RA. Hallmarks of cancer: the next generation. Cell 2011; 144: 646-674.

76 Whitfield ML, George LK, Grant GD, Perou CM. Common markers of proliferation. Nat Rev Cancer 2006; 6: 99-106.

77 Ren R. Mechanisms of BCR-ABL in the pathogenesis of chronic myelogenous leukaemia. Nat Rev Cancer 2005; 5: 172-183.

78 Wong S, Witte ON. The BCR-ABL story: bench to bedside and back. Annu Rev Immunol 2004; 22: 247-306.

79 Skorski T, Bellacosa A, Nieborowska-Skorska M, Majewski M, Martinez R, Choi JK et al. Transformation of hematopoietic cells by $B C R / A B L$ requires activation of a Pl-3k/Akt-dependent pathway. EMBO J 1997; 16: 6151-6161.

80 Vigneri $\mathrm{P}$, Wang JY. Induction of apoptosis in chronic myelogenous leukemia cells through nuclear entrapment of BCR-ABL tyrosine kinase. Nat Med 2001; 7: 228-234.

81 Aloisi A, Di Gregorio S, Stagno F, Guglielmo P, Mannino F, Sormani MP et al. $\mathrm{BCR}-\mathrm{ABL}$ nuclear entrapment kills human CML cells: ex vivo study on 35 patients with the combination of imatinib mesylate and leptomycin B. Blood 2006; 107: 1591-1598.

82 Noske A, Schwabe M, Weichert W, Darb-Esfahani S, Buckendahl AC, Sehouli J et al. An intracellular targeted antibody detects EGFR as an independent prognostic factor in ovarian carcinomas. BMC Cancer 2011; 11: 294.

83 Tabe Y, Kojima K, Yamamoto S, Sekihara K, Matsushita H, Davis RE et al. Ribosomal Biogenesis and Translational Flux Inhibition by the Selective Inhibitor of Nuclear Export (SINE) XPO1 Antagonist KPT-185. PLOS One 2015; 10: e0137210.

84 Jiao W, Lin HM, Datta J, Braunschweig T, Chung JY, Hewitt SM et al. Aberrant nucleocytoplasmic localization of the retinoblastoma tumor suppressor protein in human cancer correlates with moderate/poor tumor differentiation. Oncogene 2008; 27: 3156-3164.

85 Ishida N, Hara T, Kamura T, Yoshida M, Nakayama K, Nakayama KI. Phosphorylation of p27Kip1 on serine 10 is required for its binding to CRM1 and nuclear export. J Biol Chem 2002; 277: 14355-14358.

86 Agarwal A, Mackenzie RJ, Besson A, Jeng S, Carey A, LaTocha DH et al. BCR-ABL1 promotes leukemia by converting p27 into a cytoplasmic oncoprotein. Blood 2014; 124: 3260-3273.

87 Blain SW, Scher HI, Cordon-Cardo C, Koff A. p27 as a target for cancer therapeutics. Cancer Cell 2003; 3: 111-115.

88 Wander SA, Zhao D, Slingerland JM. p27: a barometer of signaling deregulation and potential predictor of response to targeted therapies. Clin Cancer Res 2011; 17: 12-18.

89 Wang D, He F, Zhang L, Zhang F, Wang Q, Qian X et al. The role of p27(Kip1) phosphorylation at serine 10 in the migration of malignant glioma cells in vitro. Neoplasma 2011; 58: 65-73.

90 Connor MK, Kotchetkov R, Cariou S, Resch A, Lupetti R, Beniston RG et al. CRM1/Ran-mediated nuclear export of p27(Kip1) involves a nuclear export signal and links p27 export and proteolysis. Mol Biol Cell 2003; 14: 201-213.

91 Azmi AS, Aboukameel A, Bao B, Sarkar FH, Philip PA, Kauffman M et al. Selective inhibitors of nuclear export block pancreatic cancer cell proliferation and reduce tumor growth in mice. Gastroenterology 2013; 144: 447-456.

92 Carson DA, Lois A. Cancer progression and p53. Lancet 1995; 346: 1009-1011.

93 Chene P. Inhibiting the p53-MDM2 interaction: an important target for cancer therapy. Nat Rev Cancer 2003; 3: 102-109.

94 Moll UM, Riou G, Levine AJ. Two distinct mechanisms alter p53 in breast cancer: mutation and nuclear exclusion. Proc Natl Acad Sci USA 1992; 89: 7262-7266.

95 Yang J, Bill MA, Young GS, La Perle K, Landesman Y, Shacham S et al. Novel small molecule XPO1/CRM1 inhibitors induce nuclear accumulation of TP53, phosphorylated MAPK and apoptosis in human melanoma cells. PLoS One 2014; 9: e102983.
96 Lim MJ, Wang XW. Nucleophosmin and human cancer. Cancer Detect Prev 2006; 30: $481-490$.

97 Pennisi R, Ascenzi P, di Masi A. Hsp90: a new player in DNA repair? Biomolecules 2015; 5: 2589-2618.

98 Beckham TH, Cheng JC, Lu P, Marrison ST, Norris JS, Liu X. Acid ceramidase promotes nuclear export of PTEN through sphingosine 1-phosphate mediated Akt signaling. PLoS One 2013; 8: e76593.

99 Stauber RH, Mann W, Knauer SK. Nuclear and cytoplasmic survivin: molecular mechanism, prognostic, and therapeutic potential. Cancer Res 2007; 67: 5999-6002.

100 Knauer SK, Mann W, Stauber RH. Survivin's dual role: an export's view. Cell Cycle 2007; 6: 518-521.

101 Knauer SK, Kramer OH, Knosel T, Engels K, Rodel F, Kovacs AF et al. Nuclear export is essential for the tumor-promoting activity of survivin. FASEB $J 2007 ; \mathbf{2 1}$ : 207-216.

102 Kazim S, Malafa MP, Coppola D, Husain K, Zibadi S, Kashyap T et al. Selective nuclear export inhibitor KPT-330 enhances the antitumor activity of gemcitabine in human pancreatic cancer. Mol Cancer Ther 2015; 14: 1570-1581.

103 Bartholomeusz G, Wu Y, Ali Seyed M, Xia W, Kwong KY, Hortobagyi G et al. Nuclear translocation of the pro-apoptotic Bcl-2 family member Bok induces apoptosis. Mol Carcinog 2006; 45: 73-83.

104 Arden KC. FoxOs in tumor suppression and stem cell maintenance. Cell 2007; 128: 235-237.

105 Shay JW, Wright WE. Telomerase therapeutics for cancer: challenges and new directions. Nat Rev Drug Discov 2006; 5: 577-584.

106 Harley CB. Telomerase and cancer therapeutics. Nat Rev Cancer 2008; 8: 167-179.

107 Teixeira MT, Forstemann K, Gasser SM, Lingner J. Intracellular trafficking of yeast telomerase components. EMBO Rep 2002; 3: 652-659.

$108 \mathrm{Wu} \mathrm{H}$, Becker D, Krebber H. Telomerase RNA TLC1 shuttling to the cytoplasm requires $\mathrm{mRNA}$ export factors and is important for telomere maintenance. Cell Rep 2014; 8: 1630-1638.

109 Carmeliet P, Jain RK. Angiogenesis in cancer and other diseases. Nature 2000; 407: 249-257.

110 Jain RK. Normalization of tumor vasculature: an emerging concept in antiangiogenic therapy. Science 2005; 307: 58-62.

111 Muller PA, van de Sluis B, Groot AJ, Verbeek D, Vonk WI, Maine GN et al. Nuclearcytosolic transport of COMMD1 regulates NF-kappaB and HIF-1 activity. Traffic 2009; 10: 514-527.

112 Peinado H, Olmeda D, Cano A. Snail, Zeb and bHLH factors in tumour progression: an alliance against the epithelial phenotype? Nat Rev Cancer 2007; 7: 415-428.

113 Azmi AS, Muqbil I, Wu J, Aboukameel A, Senapedis W, Baloglu E et al. Targeting the Nuclear Export Protein XPO1/CRM1 Reverses Epithelial to Mesenchymal Transition. Sci Rep 2015; 5: 16077.

114 Neufeld KL, Zhang F, Cullen BR, White RL. APC-mediated downregulation of beta-catenin activity involves nuclear sequestration and nuclear export. $E M B O$ Rep 2000; 1: 519-523.

115 Buczek ME, Miles AK, Green W, Johnson C, Boocock DJ, Pockley AG et al. Cytoplasmic PML promotes TGF-beta-associated epithelial-mesenchymal transition and invasion in prostate cancer. Oncogene 2015. e-pub ahead of print 9 November 2015; doi: 10.1038/onc.2015.409.

116 Ruggero D, Pandolfi PP. Does the ribosome translate cancer? Nat Rev Cancer 2003; 3: 179-192

117 Silvera D, Formenti SC, Schneider RJ. Translational control in cancer. Nat Rev Cancer 2010; 10: 254-266.

118 Moriggi G, Nieto B, Dosil M. Rrp12 and the Exportin Crm1 participate in late assembly events in the nucleolus during $40 \mathrm{~S}$ ribosomal subunit biogenesis. PLoS Genet 2014; 10: e1004836.

119 Golomb L, Bublik DR, Wilder S, Nevo R, Kiss V, Grabusic K et al. Importin 7 and exportin 1 link c-Myc and p53 to regulation of ribosomal biogenesis. Mol Cell 2012; 45: 222-232.

120 Thomas F, Kutay U. Biogenesis and nuclear export of ribosomal subunits in higher eukaryotes depend on the CRM1 export pathway. J Cell Sci 2003; 116: 2409-2419.

121 Siddiqui N, Sonenberg N. Signalling to elF4E in cancer. Biochem Soc Trans 2015; 43: 763-772.

122 Culjkovic B, Topisirovic I, Skrabanek L, Ruiz-Gutierrez M, Borden KL. elF4E is a central node of an RNA regulon that governs cellular proliferation. J Cell Biol 2006; 175: 415-426.

123 Siddiqui N, Borden KL. mRNA export and cancer. Wiley Interdiscip Rev RNA 2012; 3: $13-25$.

124 Elinav E, Nowarski R, Thaiss CA, Hu B, Jin C, Flavell RA. Inflammation-induced cancer: crosstalk between tumours, immune cells and microorganisms. Nat Rev Cancer 2013; 13: 759-771 
125 Cebola I, Peinado MA. Epigenetic deregulation of the COX pathway in cancer. Prog Lipid Res 2012; 51: 301-313.

126 Lu T, Stark GR. Cytokine overexpression and constitutive NFkappaB in cancer. Cell Cycle 2004; 3: 1114-1117.

127 Johnson C, Van Antwerp D, Hope TJ. An N-terminal nuclear export signal is required for the nucleocytoplasmic shuttling of IkappaBalpha. EMBO J 1999; 18: 6682-6693.

128 Ramaswami S, Manna S, Juvekar A, Kennedy S, Vancura A, Vancurova I. Chromatin immunoprecipitation analysis of NFkappaB transcriptional regulation by nuclear IkappaBalpha in human macrophages. Methods Mol Biol 2012; 809: 121-134.

129 Huang $\Pi$, Kudo N, Yoshida M, Miyamoto S. A nuclear export signal in the $\mathrm{N}$-terminal regulatory domain of IkappaBalpha controls cytoplasmic localization of inactive NF-kappaB/lkappaBalpha complexes. Proc Natl Acad Sci USA 2000; 97: 1014-1019.

130 Herbst RS, Fukuoka M, Baselga J. Gefitinib--a novel targeted approach to treating cancer. Nat Rev Cancer 2004; 4: 956-965.

131 Senderowicz AM. Development of cyclin-dependent kinase modulators as novel therapeutic approaches for hematological malignancies. Leukemia 2001; 15: 1-9.

132 Cragg MS, Harris C, Strasser A, Scott CL. Unleashing the power of inhibitors of oncogenic kinases through BH3 mimetics. Nat Rev Cancer 2009; 9: 321-326.

133 Tan DS, Bedard PL, Kuruvilla J, Siu LL, Razak AR. Promising SINEs for embargoing nuclear-cytoplasmic export as an anticancer strategy. Cancer Discov 2014; 4 527-537.

134 Turner JG, Dawson J, Sullivan DM. Nuclear export of proteins and drug resistance in cancer. Biochem Pharmacol 2012; 83: 1021-1032.

135 Turner JG, Sullivan DM. CRM1-mediated nuclear export of proteins and drug resistance in cancer. Curr Med Chem 2008; 15: 2648-2655.

136 Newlands ES, Rustin GJ, Brampton MH. Phase I trial of elactocin. Br J Cancer 1996; 74: 648-649.

137 Bonazzi S, Eidam O, Guttinger S, Wach JY, Zemp I, Kutay U et al. Anguinomycins and derivatives: total syntheses, modeling, and biological evaluation of the inhibition of nucleocytoplasmic transport. J Am Chem Soc 2010; 132: 1432-1442.

138 Koster M, Lykke-Andersen S, Elnakady YA, Gerth K, Washausen P, Hofle G et al. Ratjadones inhibit nuclear export by blocking CRM1/exportin 1. Exp Cell Res 2003; 286: 321-331.

139 Tamura S, Shimizu N, Fujiwara K, Kaneko M, Kimura T, Murakami N. Bioisostere of valtrate, anti-HIV principle by inhibition for nuclear export of Rev. Bioorg Med Chem Lett 2010; 20: 2159-2162.

140 Li FF, Yi S, Wen L, He J, Yang LJ, Zhao J et al. Oridonin induces NPM mutant protein translocation and apoptosis in NPM1c+ acute myeloid leukemia cells in vitro. Acta Pharmacol Sin 2014; 35: 806-813.

141 Watanabe K, Takatsuki H, Sonoda M, Tamura S, Murakami N, Kobayashi N. Anti-influenza viral effects of novel nuclear export inhibitors from Valerianae Radix and Alpinia galanga. Drug Discov Ther 2011; 5: 26-31.

142 Niu M, Wu S, Mao L, Yang Y. CRM1 is a cellular target of curcumin: new insights for the myriad of biological effects of an ancient spice. Traffic 2013; 14 1042-1052.

143 Wach JY, Guttinger S, Kutay U, Gademann K. The cytotoxic styryl lactone goniothalamin is an inhibitor of nucleocytoplasmic transport. Bioorg Med Chem Lett 2010; 20: 2843-2846.

144 Liu X, Niu M, Xu X, Cai W, Zeng L, Zhou X et al. CRM1 is a direct cellular target of the natural anti-cancer agent plumbagin. J Pharmacol Sci 2014; 124: 486-493.

145 Kau TR, Schroeder F, Ramaswamy S, Wojciechowski CL, Zhao JJ, Roberts TM et al. A chemical genetic screen identifies inhibitors of regulated nuclear export of a Forkhead transcription factor in PTEN-deficient tumor cells. Cancer Cell 2003; 4: 463-476.

146 Lu Y, Zhou Q, Zhong F, Guo S, Hao X, Li C et al. 15-Deoxy-Delta(12,14)prostaglandin $\mathrm{J}(2)$ modulates lipopolysaccharide-induced chemokine expression by blocking nuclear factor-kappaB activation via peroxisome proliferator activated receptor-gamma-independent mechanism in renal tubular epithelial cells. Nephron Exp Nephrol 2013; 123: 1-10.

147 Zhang F, Zhang T, Jiang T, Zhang R, Teng ZH, Li C et al. Wortmannin potentiates roscovitine-induced growth inhibition in human solid tumor cells by repressing PI3K/Akt pathway. Cancer Lett 2009; 286: 232-239.

148 Scher JU, Pillinger MH. 15d-PGJ2: the anti-inflammatory prostaglandin? Clin Immunol 2005; 114: 100-109.

149 Hilliard M, Frohnert C, Spillner C, Marcone S, Nath A, Lampe T et al. The anti-inflammatory prostaglandin 15-deoxy-delta(12,14)-PGJ2 inhibits CRM1dependent nuclear protein export. J Biol Chem 2010; 285: 22202-22210.

150 Daelemans D, Afonina E, Nilsson J, Werner G, Kjems J, De Clercq E et al. A synthetic HIV-1 Rev inhibitor interfering with the CRM1-mediated nuclear export. Proc Natl Acad Sci USA 2002; 99: 14440-14445.
151 Sakakibara K, Saito N, Sato T, Suzuki A, Hasegawa Y, Friedman JM et al. CBS9106 is a novel reversible oral CRM1 inhibitor with CRM1 degrading activity. Blood 2011; 118: 3922-3931.

152 Niu M, Chong Y, Han Y, Liu X. Novel reversible selective inhibitor of nuclear export shows that CRM1 is a target in colorectal cancer cells. Cancer Biol Ther 2015; 16: 1110-1118.

153 Monovich L, Koch KA, Burgis R, Osimboni E, Mann T, Wall D et al. Suppression of HDAC nuclear export and cardiomyocyte hypertrophy by novel irreversible inhibitors of CRM1. Biochim Biophys Acta 2009; 1789: 422-431.

154 Saito N, Sakakibara K, Sato T, Friedman JM, Kufe DW, VonHoff DD et al. CBS9106-induced CRM1 degradation is mediated by cullin ring ligase activity and the neddylation pathway. Mol Cancer Ther 2014; 13: 3013-3023.

155 Crochiere ML, Baloglu E, Klebanov B, Donovan S, Del Alamo D, Lee M et al. A method for quantification of exportin-1 (XPO1) occupancy by selective inhibitor of nuclear export (SINE) compounds. Oncotarget 2016; 7: 1863-1877.

156 Hamamoto T, Uozumi T, Beppu T. Leptomycins A and B, new antifungal antibiotics. III. Mode of action of leptomycin B on Schizosaccharomyces pombe. J Antibiot 1985; 38: 1573-1580.

157 Clardy J, Fischbach MA, Walsh CT. New antibiotics from bacterial natural products. Nat Biotechnol 2006; 24: 1541-1550.

158 Hamamoto T, Seto H, Beppu T. Leptomycins A and B, new antifungal antibiotics. II. Structure elucidation. J Antibiot 1983; 36: 646-650.

159 Lu C, Shao C, Cobos E, Singh KP, Gao W. Chemotherapeutic sensitization of leptomycin B resistant lung cancer cells by pretreatment with doxorubicin. PLoS One 2012; 7: e32895.

160 Kudo N, Wolff B, Sekimoto $T$, Schreiner EP, Yoneda $Y$, Yanagida $M$ et al. Leptomycin $B$ inhibition of signal-mediated nuclear export by direct binding to CRM1. Exp Cell Res 1998; 242: 540-547.

161 Sun Q, Carrasco YP, Hu Y, Guo X, Mirzaei H, Macmillan J et al. Nuclear export inhibition through covalent conjugation and hydrolysis of Leptomycin $B$ by CRM1. Proc Natl Acad Sci USA 2013; 110: 1303-1308.

162 Chook Y. Signals and blockers in karyopherin-mediated transport. FASEB J 2015; 28: 238.231.

163 Etchin J, Sun Q, Kentsis A, Farmer A, Zhang ZC, Sanda T et al. Antileukemic activity of nuclear export inhibitors that spare normal hematopoietic cells. Leukemia 2013; 27: 66-74.

164 Haines JD, Herbin O, de la Hera B, Vidaurre OG, Moy GA, Sun Q et al. Nuclear export inhibitors avert progression in preclinical models of inflammatory demyelination. Nat Neurosci 2015; 18: 511-520.

165 Breit MN, Kisseberth WC, Bear MD, Landesman Y, Kashyap T, McCauley D et al. Biologic activity of the novel orally bioavailable selective inhibitor of nuclear export (SINE) KPT-335 against canine melanoma cell lines. BMC Vet Res 2014; 10: 160.

166 Fornerod M, Ohno M, Yoshida M, Mattaj IW. CRM1 is an export receptor for leucine-rich nuclear export signals. Cell 1997; 90: 1051-1060.

167 Henderson BR, Eleftheriou A. A comparison of the activity, sequence specificity, and CRM1-dependence of different nuclear export signals. Exp Cell Res 2000; 256: 213-224.

168 Ranganathan $\mathrm{P}, \mathrm{Yu}$ X, Na C, Santhanam R, Shacham S, Kauffman M et al. Preclinical activity of a novel CRM1 inhibitor in acute myeloid leukemia. Blood 2012; 120: 1765-1773.

169 Conforti F, Wang Y, Rodriguez JA, Alberobello AT, Zhang YW, Giaccone G. Molecular pathways: anticancer activity by inhibition of nucleocytoplasmic shuttling. Clin Cancer Res 2015; 21: 4508-4513.

170 Parikh K, Cang S, Sekhri A, Liu D. Selective inhibitors of nuclear export (SINE)--a novel class of anti-cancer agents. J Hematol Oncol 2014; 7: 78.

171 Neggers JE, Vercruysse T, Jacquemyn M, Vanstreels E, Baloglu E, Shacham S et al. Identifying drug-target selectivity of small-molecule CRM1/XPO1 inhibitors by CRISPR/Cas9 genome editing. Chem Biol 2015; 22: 107-116.

172 Van Neck T, Pannecouque C, Vanstreels E, Stevens M, Dehaen W, Daelemans D. Inhibition of the CRM1-mediated nucleocytoplasmic transport by $\mathrm{N}$-azolylacrylates: structure-activity relationship and mechanism of action. Bioorg Med Chem 2008; 16: 9487-9497.

173 Mah R, Thomas JR, Shafer CM. Drug discovery considerations in the development of covalent inhibitors. Bioorg Med Chem Lett 2014; 24: 33-39.

174 Kalgutkar AS, Dalvie DK. Drug discovery for a new generation of covalent drugs. Expert Opin Drug Discov 2012; 7: 561-581.

175 Serafimova IM, Pufall MA, Krishnan S, Duda K, Cohen MS, Maglathlin RL et al. Reversible targeting of noncatalytic cysteines with chemically tuned electrophiles. Nat Chem Biol 2012; 8: 471-476.

176 Liu Y, Jiang N, Wu J, Dai W, Rosenblum JS. Polo-like kinases inhibited by wortmannin. Labeling site and downstream effects. J Biol Chem 2007; 282: 2505-2511.

177 London CA, Bernabe LF, Barnard S, Kisseberth WC, Borgatti A, Henson M et al. Preclinical evaluation of the novel, orally bioavailable Selective Inhibitor of 
Nuclear Export (SINE) KPT-335 in spontaneous canine cancer: results of a phase I study. PLoS One 2014; 9: e87585.

178 Abdul Razak AR, Mau-Soerensen M, Gabrail NY, Gerecitano JF, Shields AF, Unger TJ et al. First-in-class, first-in-human phase I study of Selinexor, a selective inhibitor of nuclear export, in patients with advanced solid tumors. J Clin Oncol 2016; e-pub ahead of print 29 February 2016.

179 Crochiere M, Kashyap T, Kalid O, Shechter S, Klebanov B, Senapedis W et al. Deciphering mechanisms of drug sensitivity and resistance to selective inhibitor of nuclear export (SINE) compounds. BMC Cancer 2015; 15: 910. (c) This work is licensed under a Creative Commons Attribution 4.0 International License. The images or other third party material in this article are included in the article's Creative Commons license, unless indicated otherwise in the credit line; if the material is not included under the Creative Commons license, users will need to obtain permission from the license holder to reproduce the material. To view a copy of this license, visit http://creativecommons.org/licenses/by/4.0/

(c) The Author(s) 2016 